\title{
PERAN KEPEMIMPINAN KEPALA SEKOLAH BERBASIS KEARIPAN LOKAL SASAK DALAM PENINGKATAN KEDISIPLINAN KERJA GURU
}

\author{
Muzakki \\ Universitas Hamzanwadi \\ zakimuzaki08@gmail.com
}

\begin{abstract}
The purpose of this study was to determine the leadership role of principals in improving the work discipline of NW NW Rumbuk teachers, so the authors present a theoretical study which presents theories related to the problem of this research. This study is located in MA NW Rumbuk Kec. Sakra, with research subjects namely principals, teachers and employees. Data collection techniques are carried out by observation, interviews, and documentation. By analyzing the data using Milles and Huberman model analysis. Based on the results of the study can provide an interpretation of the findings in the field, it can be said that, 1. Principals as managers have a strong role, coordinate, move and integrate all educational resources in schools. 2. Principals as educators of things that are taught by the principal are intelligence of the mind. 3. Principals as administrators, namely the principal must be able to carry out his duties properly. 4. Principals as motivators, principals are a very important part of school.
\end{abstract}

Keywords: School Principal Role, Sasak Local Practice, Teacher Work Discipline.

\begin{abstract}
Abstrak
Tujuan penelitian ini adalah untuk mengetahui peran kepemimpinan kepala sekolah dalam meningkatkan kedisiplinan kerja guru MA NW Rumbuk, maka penulis menyajikan kajian teori yang memaparkan teori-teori yang berkaitan dengan masalah penelitian ini. Penelitian ini berloksi di MA NW Rumbuk kec. Sakra, dengan subjek penelitian yaitu kepala sekolah, guru dan pegawai. Teknik pengumpulan data dilakukan dengan cara observasi, wawancara, dan dokumentasi. Dengan analisis datanya menggunakan anlisi model Milles dan Huberman. Berdasarkan hasil penelitian dapat memberikan interpretasi terhadap hasil penemuan dilapangan maka dapat dikatakan bahwa, 1. Kepala Sekolah sebagai manajer memiliki peran yang kuat, mekoordinasi, menggerakkan dan menyelerasikan semua sumberdaya pendidikan di sekolah. 2. Kepala Sekolah sebagai pendidik hal yang di didik kepala sekolah adalah kecerdasan pikiran. 3. Kepala Sekolah sebagai administrator yaitu kepala sekolah harus mampu mengusai tugas-tugasya dengan baik. 4. Kepala Sekolah sebagai motivator, kepala sekolah yang merupakan suatu bagian yang sangat penting di sekolah.
\end{abstract}

Kata kunci: Peran Kepala Sekolah, Kearipan Lokal Sasak, Kedesiplinan Kerja guru 


\section{PENDAHULUAN}

Proses belajar (pendidikan) adalah proses yang dimana seseorang diajarkan untuk bersikap setia dan taat juga pikirannya dibina dan dikembangkan. Pendidikan bagi bangsa yang sedang berkembang seperti bangsa Indonesia saat ini merupakan kebutuhan mutlak yang tidak bisa ditawar lagi, perkembangan pendidikan juga harus sejalan dengan tuntunan pembangunan setahap demi setahap. Berdasarkan Undang-Undang No.20 Tahun 2003, telah di gariskan bahwa:

"Pendidikan Nasional bertujuan mencerdaskan kehidupan bangsa dan mengembangkan manusia Indonesia seutuhnya, yaitu manusia yang beriman dan bertakwa kepada Tuhan Yang Maha Esa dan berbudi pekerti luhur, memiliki pengetahuan dan keterampilan, kesehatan jasmani dan rohani, kepribadian yang mantap dan mandiri serta rasa tanggung jawab kemasyarakatan dan kebangsaan" (RI No, 2003:30).

Kepala sekolah mempunyai posisi yang sangat penting dalam memelihara dan memperbaiki kualitas sekolah.Kepala sekolah bertanggung jawab sepenuhnya terhadap kelancaran pelaksanaan pendidikan dan pengajaran di sekolahnya.Banyaknya tugas dan tanggung jawab tersebut membuat posisi kepala sekolah menjadi penting dan menantang.Oleh masyarakat dan pemerintah, kepala sekolah dituntut bertanggung jawab atas efektif tidaknya penyelenggaraan pendidikan di sekolah. Oleh pihak guru, kepala sekolah dituntut untuk dapat mengembangkan iklim sekolah yang kondusif bagi kelancaran proses belajar mengajar.

Sebagai administrator pendidikan di sekolah, kepala sekolah menghadapi berbagi problem.Salah satu problem yang menuntut perhatian kepala sekolah adalah masalah disiplin kerja warga sekolah dalam mewujudkan tujuan sekolah. Selain itu juga pemimpin memiliki peran yang sangat luas, mulai dari lingkungan sekolah sampai pada kesiswaan.Namun peran yang sedang dijalankan oleh seorang pemimpin harus mampu menuju suatu perubahan, baik itu perubahan system maupun perubahan yang lainnya.

Dari pernyataan-pernyataan tersebut, dapat disimpulkan bahwa setiap tingkah laku kepala sekolah sebagai pemimpin pendidikan di arahkan untuk mencapai tujuan pendidikan, dan salah satu faktor penting untuk mencapai tujuan terebut adalah adanya disiplin kerja staf sekolah. Oleh karena itu, dalam menerapkan disiplin secara konsisten harus dimulai dari disiplin para guru di sekolah dan disiplin para guru tentunya harus di bina oleh pimpinan sekolah yang benar-benar konsisten. Sesuai peraturan pemerintah No. 38 Tahun 1992 pasal 28 menyatakan bahwa pembinaan disiplin tenaga 
kependidikan merupakan tanggung jawab pimpinan satuan pendidikan yang bersangkutan.

Kepemimpinan dan kearipan lokal yang Ada berbagai defenisi dan pengertian kepemimpinan yang dikemukakan oleh para ahli dengan sudut pandang yang berbeda. Pengertian kepemimpinan menurut Effendi (2005), menunjukkan suatu proses kegiatan seseorang dalam memimpin, membimbing, mengontrol pikiran, perasaan, atau tingkah laku orang lain.

Wahjosumidjo (2007), menjelaskan bahwa kepemimpinan merupakan hubungan kekuatan dan kekuasaan, kepemimpinan sebagai suatu bentuk hubungan sekelompok orang, hubungan antara yang memimpin dengan yang dipimpin, dimana hubungan tersebut mencerminkan seseorang atau sekelompok orang berperilaku karena akibat adanya kewibawaan yang ada.

Ma'rat (2001) menyatakan bahwa kepemimpinan merupakan ciri-ciri aktivitas seseorang yang dapat mengendalikan pengikutnya. Selain itu sebagai instrumen yang memiliki aspek-aspek untuk dapat melancarkan suatu kegiatan. Menurut Soekanto (2002), kepemimpinan adalah kemampuan dari seseorang yaitu pemimpin untuk mempengaruhi orang lain sehingga orang lain tersebut bertingkah laku sebagaimana dikehendaki.

Pengertian kepemimpinan juga mencakup kepemimpinan formal dan informal.Kepemimpinan formal diartikan sebagai kepemimpinan yang melekat pada seseorang yang memiliki kekuatan pribadi dan kekuatan posisional secara sekaligus, sedangkan kepemimpinan informal diartikan sebagai kepemimpinan yang melekat pada seseorang yang mampu mengendalikan bawahannya hanya berdasarkan pada kekuatan pribadi (Etzioni.1985).

I Wayan Geriya (2002), mejelaskan bahwa kearifan lokal merupakan bagian dari kebudayaan tradisional yang secara subtantif berorientasi pada keseimbangan dan harmoni manusia, alam, budaya, kelestarian, keragaman alam dan kultur, konservasi alam dan warisan budaya serta penghematan sumberdaya yang ada. Dengan demikian terdapat kesamaan antara makna tentang kepemimpinan. Kepemimpinan dapat didefinisikan sebagai suatu cara mengendalikan orang lain agar mau mengikuti apa yang diinginkan dalam rangka mencapai tujuan bersama. Dan Kearifan Lokal adalah suatu pengetahuan lokal dalam suatu komunitas berkenaan dengan nilai-nilai, norma-norma serta adat istiadat yang dipelihara masyarakat secara turuntemurun dalam menjaga kelestarian sumber daya alam daerahnya.

\section{METODE PENELITIAN}

Adapun jenis penelitian yang digunakan adalah Deskriptif-Kualitatif. Dimana metode deskriptif itu adalah pencarian fakta dengan interpretasi yang tepat. Penelitian deskriptif mempelajari masalah-masalah dalam masyarakat serta situasi-situasi tertentu, termasuk tentang hubungan- 
hubungan, kegiatan, kegiatan, sikap-sikap, pandangan-pandangan serta proses-proses yang sedang berlangsung dari suatu fenomena.

Penelitian sosial menggunakan format deskriptif kualitatif bertujuan untuk mengkritik kelemahan penelitian kuantitatif (yang terlalu positivisme), serta juga bertujuan untuk menggambarkan, meringkas berbagai kondisi, berbagai situasi stau berbagai fenomena realitas soaial yang ada dimasyarakat yang menjadi objek penelitian, dan berupaya untuk menarik realitas itu kepermukaan sebagai suatu ciri, karakter, sifat, model, tanda, atau gambaran tentang kondisi, situasi, ataupun fenomena tertentu (Bungin, 2008:68).

Alasan penggunaan jenis pendekatan ini adalah jenis ini lebih tepat digunakan untuk menggambarkan bagaimana "Peran Organisasi Kepemudaan Persatuan Remaja Harapan Maju Dalam Peningkatan Solidaritas Antar Pemuda" yang memang membutuhkan suatu penjelasan yang sangat spesifik. Dengan mempelajari setiap permasalahan yang dihadapi oleh masyarakat. dan mencari tahu apa yang dapat meningkatkan solidaritas antar pemuda. Yang menjadi sumber data dalam penelitian ini adalah data primer yang diambil dari observasi dan wawancara, yang dilakukan dengan subjek penelitian, sedangkan data sekundernya menggunakan foto-foto dan tape rekaman.

Dalam rangka mempermudah proses pengumpulan data dan untuk mengangkat data yang dikumpulkan, penulis harus mampu memilih teknik dan strategi yaitu, memilih dan menetapkan metode yang efektif, efesien dan tepat guna serta relevan dengan jenis data yang hendak dikumpulkan. Pengumpulan data merupakan langkah yang sangat penting dalam penelitian, bagaimanapun mantapnya rencana yang dipersiapkan, apabila kegiatan pengumpulan data tidak terlaksana dengan baik maka tujuan yang ditetapkan tidak akan tercapai dengan baik juga. Oleh karena itu, seorang peneliti harus terampil dalam mengumpulkan data agar mendapatkan data yang valid.

Pengumpulan data dapat dilakukan dengan berbagai setting, sumber dan berbagai cara. Tehnik pengumpulan data merupakan langkah yang paling strategis dalam penelitian, karena tujuan utama dari penelitian adalah mendapatkan data. Tanpa mengetahui tehnik pengumpulan data, maka peneliti tidak akan mendapatkan data yang memenuhi standar data yang ditetapkan. Untuk mengadakan atau mengumpulkan sebagai jalan pendukung dalam melaksanakan penelitian ini maka penulis akan mengumpulkan data dengan menggunakan beberapa metode antara lain Observasi Berperan Serta (Participant Observation), Wawancara Tak Terstruktur Dan Dokumentasi.

Dalam menganalisis data tersebut, peneliti menggunakan analisis model Miles dan Huberman. Pada model analisis Miles dan Huberman tiga 
macam kegiatan yaitu Data Reduction (reduksi data), Data Display (penyajian data), dan Verivication (penarikan kesimpulan).

\section{HASIL PENELITIAN DAN PEMBAHASAN Peran Kepala Sekolah Dalam Peningkatan Kedisiplinan Kerja Guru di MA NW Rumbuk}

Terkait dengan peran kepemimpinan dan meningkatkan mutu pendidikan di lembaga sekolah, tentu akan mengalami peningkatan manakala disiplin dan kinerja guru saling berimbang di bawah kepemimpinan kepala sekolah sebagai unsur pembuat keputusan tertinggi di sekolah. Hubungan ini dapat berlangsung secara timbal balik dan saling mempengaruhi bila ditinjau dan dikaji secara holistis. Namun pembahasan dalam bagian ini akan di paparkan tentang begitu besarnya peran kepemimpinan kepala sekolah dalam peningkatan kedisiplinan kerja guru di MA NW Rumbuk, berdasarkan hasil penelitian yang telah dilakukan. Adapun peran kepala sekolah yang ditemukan adalah:

1. Kepala sekolah sebagai manajer, memiliki peran yang kuat dalam mengkoordinasikan, menggerakkan, mengelola dan menyelerasikan semua sumber daya pendidikan yang tersedia di sekolah. Kepala sekolah tetap mengawasi, melakukan control serta evaluasi setiap program dan kinerja guru, dan sebagi manajer kepala sekolah wajib harus bisa memaksimalkan sumberdaya pendidikan yang ada.

2. Kepala sekolah sebagai pendidik, hal yang di didik kepala sekolah adalah kecerdasan pikiran sehingga pendidikan dapat diartikan proses pengubahan sikap dan tata laku seseorang atau kelompok orang dalam usaha mendewasakan manusia melalui pengajaran dan pelatihan.

3. Kepala Sekolah sebagai administrator yaitu, kepala sekolah harus mampu menguasai tugas-tugasnya dan melaksanakan tugasnya dengan baik. Untuk itu kepala sekolah harus kreatif mampu memiliki ide-ide dan inisiatif yang menunjang perkembangan sekolah.

Demikian pula seorang pekasih yang merupakan ujung tombak bagi pemerintah dalam proses pertanian khususnya dibidang irigasi, yang tentunya peran dan kinerjanya sangat dibutuhkan dalam membantu pemerintah menjalankan program-programnya dalam pertanian dan membantu petani dalam menjalankan pertaniannya tentu dengan tugas-tugas yang sudah menjadi kewajibannya. Seorang pekasih harus betul-betul paham akan tugasnya, sebab jika pekaseh tidak paham dan teliti dalam menjalankan tuga-tugasnya akan berpengaruh pada keseimbangan keharmonisan para petani yang dibawahinya.

Terkait dengan peran kepemimpinan dan meningkatkan mutu pendidikan di lembaga sekolah, tentu akan mengalami peningkatan manakala disiplin dan kinerja guru saling berimbang di bawah kepemimpinan kepala sekolah sebagai unsur pembuat keputusan tertinggi di sekolah. Hubungan ini 
dapat berlangsung secara timbal balik dan saling mempengaruhi bila ditinjau dan dikaji secara holistis. Namun pembahasan dalam bagian ini akan di paparkan tentang begitu besarnya peran kepemimpinan kepala sekolah dalam peningkatan kedisiplinan kerja guru di MA NW Rumbuk, berdasarkan hasil penelitian yang telah dilakukan. Hasil wawancara dengan Zuhdil Amri, S.Pd yaitu Guru Mapel Biologi/Mulok

"Biasanya para guru sudah berada di sekolah sebelum pelajaran dimulai yaitu pada jam 07.15 - 07.30 wita, bila ada guru yang terlambat biasanya langsung terkena teguran dari kepala sekolah. Sehingga, minimal para guru sudah harus sampai di sekolah sekitar jam 07.00 tepat. (Wawancara 20 Januari 2017).

Hasil wawancara di atas sesuai dengan hasil wawancara dengan bapak Ahmad Riyadi, S.Ag guru mapel Agama Islam dan Dra. Tuti Seni Handayani guru BP/BK:

"Apalagi meninggalkan sekolah tanpa ada izin dari kepala sekolah, akan menimbulkan perasaan malu bagi guru yang sering izin keluar sekolah, selain itu juga pada kegiatan-kegiatan yang menyangkut sekolah seperti upacara bendera, kegiatan keagamaan yang seringkali kepala sekolah tetap hadir, sedangkan pegawai maupun guru jarang mengikuti acara tersebut, paling-paling hanya mengikuti atau mengawasi siswa saja, sehingga hal tersebut membuat para guru/pegawai merasa malu terhadap kepala sekolah (pimpinan)" (Wawancara 20 Januari 2017).

Sesuai dengan hasil penelitian, para guru MA NW Rumbuk memiliki sikap yang baik apalagi jika dilihat dari segi berpakaian dan berbicaranya. Bukan itu saja di dalam kelas para guru sudah menunjukkan kerapiannya yaitu letak meja, kursi, gambar dinding yang teratur, penempatan papan absen dan lantai yang bersih sehingga menciptakan rasa aman dan nyaman bagi guru dan siswanya. Terbukti dari hasil wawancara dengan salah satu guru yaitu Drs. Suryatman guru mapel Bhs. Indo:

"Dalam segi kerapian dan kesopanan memang harus dipelihara karena menunjukkan etika baik kepada siswa, sekolah dan masyarakat, terutama sekali jika berada di dalam kelas harus sudah bersih dan letak kursi, meja papan absen, lap, cuci tangan harus di letakkan sesuai, karena kalau kerapian dan kesopanan guru baik di dalam maupun di luar kelas sudah tidak rapi akan membawa pengaruh yang besar terhadap kelancaran dan kenyamanan belajar siswa, terutama sikap guru memang harus dijaga karena secara tidak langsung siswa meresponnya".(Wawancara 22 Januari 2017). 
Hasil identifikasi kriteria yang telah di tentukan peneliti tentang kedisiplinan kerja guru di atas sangat besar dipengaruhi oleh peran kepala sekolah dalam berbagai hal. Peran kepala sekolah dapat diketahui, manakala guru merasakan betul adanya peran kepala sekolah dalam peningkatan kedisiplinan terutama dalam hal kerja guru, merasakan peran kepemimpinan tersebut bagi dirinya, begitupun pula dengan kepala sekolah ia dapat melihat perubahan tingkat disiplin kerja guru tersebut selama ia menerapkan keperibadian dan gaya kepemimpinannya, serta akan tampak pada penerimaan guru terhadap gaya kepemimpinan kepala sekolah. Selama kepemimpinan kepala sekolah MA NW Rumbuk yang sekarang, terdapat peningkatan yang cukup signifikan mengenai presentase jumlah kelulusan siswa dibandingkan tahun-tahun sebelumnya. Ini menunjukan bahwa guru telah dapat menjalankan kerjanya dengan baik.

Kepala sekolah MA NW Rumbuk menekankan pada aspek disiplin waktu, hal ini terlihat ada dirinya, mulai dari disiplin waktu, cara berpakaian, berbicara, berkomunikasi dengan para guru, pegawai dan siswa bahkan dengan penjaga sekolah seperti satu keluarga. Bahwa kepala sekolah telah berusaha untuk menunjukkan suatu hal yang sifatnya disiplin kepada para guru dan pegawai, sehingga rasanya malu jika guru sendiri telambat datang ke sekolah., sedangkan atasannya selalu hadir lebih dahulu dari bawahannya. Ini membuktikan bahwa segala apa yang dikerjakan dan diharapkan harus dengan rasa disiplin, dan disiplin itu harus dengan kesadaran diri, dan semua itu tidak terlepas dari peran serta pemimpin (kepala sekolah).

Selain itu juga, kepala sekolah menjalin hubungan kerja yang sudah diterapkan tidak ampai membuat guru tertekan, kaku dan menimbulkan masalah yang dapat mengganggu hubungan kerja itu sendiri. Apalagi manakala di topang oleh cukup baiknya hubungan emosional yang dibangun kepala sekolah di sela-sela aspek disiplin yang diterapkan dalam menjalankan fungsinya masing-masing. Membangun hubungan emosional pemimpin (kepala sekolah).

\section{PEMBAHASAN}

Kepemimpinan Kepala Sekolah adalah cara atau usaha kepala sekolah dalam mempengaruhi, mendorong, membimbing, mengarahkan, dan menggerakkan guru, staf, siswa, orang tua siswa dan pihak lain yang terkait untuk bekerja atau berperan serta dalam usaha mencapai tujuan yang telah ditetapkan. Oleh karena itu kepala sekolah selalu melakukan control dan evalusi bawahwanya demi tercapainya sebuah kedisiplinan dan meningkatnya kualitas kinerja guru.

Setiap masalah yang muncul haruslah diselesaikan. Jiwa kepemimpinan akan mampu menanggulangi setiap masalah yang muncul. Tiga hal untuk mengembangkan jiwa kepemimpinan Kepala MA NW Rumbuk diantaranya sebagai berikut: 
1. Keterampilan teknis (technical skill)

Yaitu kemampuan untuk menggunakan pengetahuan, metode prosedur, teknik dan akal yang diperlukan untuk melaksanakan tugas spesifik yang diperoleh lewat pengalaman, pendidikan, dan pelatihan keterampilan. Keterampilan kepala sekolah seperti keterampilan konsep keterampilan humanis dan keterampilan teknis. Adapun bentuk-bentuk keterampilan kepala sekolah yang menjadi landasan kearipan lokal sasak: (1). Tao/ceket, artinya adalah kepala sekolah memiliki keterampilan yang serba bisa, bentuk keterampilan ini dibutuhkan oleh setiap kepala sekolah agar bisa mendidik para guru dan pegawainya. (2). Onyak-onyak, artinya kepala sekolah berhati-hati dalam bertindak-tanduk, apalagi dalam mengambil semua keputusan terkait dengan masa depan sekolah. (3). Lombok, artinya kepala sekolah memiliki sifat yang jujur, lurus agar dapat dipercaya oleh. (4). Smaik-maik, artinya kepala sekolah tidak boleh berlebih-lebihan baik dalam sifat maupun dalam segala hal. (5). Saling laik, artinya saling menyambangi antara kepala sekolah dengan guru dan atau wali murid sebagai silaturrahmi, agar tumbuh kedekatan yang baik. (6). Sesiru, artinya saling tolong menolong atau batu membantu dalam menyelesaikan dan menjalankan tugas-tugas sekolah. (7). Saling sangkep, artinya saling bertukar pikiran atau musyawarah dalam melakukan dan menyelesaikan tugas-tugas seklah. (8). Gundem, artinya bercakap cakap, atau melakukan candaan.

Manajer membutuhkan keterampilan teknis yang cukup untuk menjalankan alat (mekanik) dari suatu pekerjaan tertentu yang menjadi tanggung jawabnya, hal ini sesuai dengan apa yang di ungkapkan oleh Pak Rohman, S.Pd selaku kepala sekolah dia mengungkapkan bahwa:

"Sebagai manajer kepala sekolah harus mau dan mampu mendaya gunakan seluruh sumber daya sekolah dalam neingkatkan visi, misi dan mencapai tujuan. Kepala sekolah mewajibkan setiap guru mata pelajaran harus melaksanakan proses pembelajaran yang mengacu pada standar kelulusan dan melaksanakan musyawarah guru mata pelajaran yang ada di sekolah (Wawancara, 11 Januari 2017)"

Dari hasil wawancara di atas sesuai dengan hasil observasi peneliti bahwa kepala sekolah merupakan manajer bagi guru dan siswa, oleh karena itu kepala sekolah MA NW Rumbuk selalu menyadaya gunakan guru dan siswa serta menciptakan kerja sama yang harmonis demi tercapainya kedisiplinan guru.

Kepala sekolah sebagai manejer memiliki peran yang kuat dalam mengkoordinasikan, menggerakkan dan menyelerasikan semua sumber daya pendidikan yang tersedia di sekolah. Oleh karena itu kepala sekolah dituntut mempunyai kemampuan menajemen dan kepemimpinan yang 
memadai agar mampu mengambil inisiatif dan prakarsa untuk meningkatkan mutu sekolah. Di samping itu kepala sekolah harus mampu merencanakan setiap kegiatan di sekolah maupun dalam segi meningkatkan kedisiplinan guru.

Dari gambaran diatas sesuai dengan hasil wawancara peneliti dengan Pak Rohman selaku kepala sekolah MA NW Rumbuk, dia mengungkapkan bahwa :

"Kepala sekolah sebagai manajer harus mampu merencanakan setiap tindakan yang akan diterapkan disekolah, sebaiknya setiap kegiatan yang akan dilaksanakan tidak boleh terlepas dari proses perencanaan, sebab semua kegiatan sekolah bisa sukses karena pada umumnya direncanakan dengan matang" (Wawancara, 11 Januari 2017).

2. Keterampilan manusiawi (human skill)

Yaitu kemampuan dan pertimbangan yang diusahakan bersama orang lain, termasuk pemahaman mengenai motivasi dan aplikasi tentang kepemimpinan yang efektif. Manajer cukup memiliki keterampilan hubungan manusiawi agar dapat bekerja dengan para bawahan dalam organisasi dan mengelola kelompoknya sendiri.tindih yaitu pandangan hidup orang orang sasak Lombok.

Tindih diungkapkan dalam bentuk tertib tapsile sebagai nilai-nilai pemandu terbangunnya kebudayaan dan peradaban sasak. Tindih ini kemudian diimplementasikan menjadi dasar dalam pembuatan hukum tradisi sasak (awik-awik) yang mengatur tata cara manusia berhubungan dengan sesamanya dan alamnya beserta beban sanksi apabila terjadi pelanggaran dalam proses pelaksanaannya.

Peran kepala sekolah berikutnya adalah sebagai pendidik dimana dalam hal ini kepala sekolah mendidik kedisiplinan guru. Upaya mendidik kedisiplinan guru dilakukan dengan membuatkan jadwal piket dan membuat aturan ketepatan masuk dan keteladanan guru, hal ini sesuai dengan apa yang di ungkapkan oleh Guru sosiologi Ma Nw rumbuk, dia mengungkapkan bahwa:

"Peran kepala sekolah kami di sini dalam meningkatkan kedisplinan para guru adalah dengan cara mendidik kami agar menjadi guru yang disiplin serta berkompeten di segala bidang." (Wawancara, 11 Januari 2017).

Hasil wawancara di atas sesuai juga dengan hasil wawancara dengan Siswa Ma NW Rumbuk Dayah, dia mengungkapkan bahwa:

"Peran sekolah Ma NW Rumbuk dalam mendidik dia sangat berperan dalam mendidik siswa dan guru maupun pegawai dengan membuat aturan-aturan yang berkualitas dan harus 
ditaati oleh semua guru dan siswa." (Wawancara, 11 Januari 2017).

3. Keterampilan konseptual (conceptual skill)

Yaitu kemampuan memahami kompleksitas keseluruhan organisasi tempat seseorang beradaptasi dalam operasi. Pengetahuan tersebut membenarkan seseorang bertindak sesuai dengan tujuan keseluruhan organisasi, daripada hanya dijadikan dasar tujuan umum dan kebutuhan kelompok yang mendesak. Manajer memerlukan keterampilan konseptual yang cukup untuk mengenali bagaimana berbagai macam faktor pada suatu kondisi tertentu berkaitan satu sama lain.

Dengan demikian, tindakan yang diambilnya akan ditujukan untuk kepentingan organisasi secara keseluruhan Gambaran diatas sesuai dengan hasil wawancara yang diungkapkan oleh Wakil Kepala sekolah bagian Kesiswaan dia mengungkapkan bahwa:

"Peran Kepala sekolah MA NW Rumbuk kompleksitas keseluruhan organisasi tempat seseorang beradaptasi dalam operasi tidak terlepas dari pengelolaan administrasi yang bersifat pencatatan dan pendokumentasian seluruh program sekolah. Oleh sebab itu tugas menjadi Kepala sekolah sangatlah berat karena dituntut memahami dan mengelola kurikulum, administrasi peserta didik, administrasi sarana dan prasarana, dan administrasi kearsipan." (Wawancara, 12 Januari 2017).

Untuk terlakasanya peran kepala sekolah sebagai kompleksitas keseluruhan organisasi tempat seseorang beradaptasi dalam operasi dan terlaksana dengan baik. Kemampuan kepala sekolah sebagai administrator harus diwujudkan dalam penyusunan kelengkapan data administrasi pembelajaran, bimbingan dan konseling, kegiatan praktikum, kegiatan di perpustakaan, data administrasi peserta didik, guru, pegawai TU, penjaga sekolah, teknisi dan pustakawan, kegiatan ekstrakurikuler, data administrasi hubungan sekolah dengan orang tua murid, data administrasi gedung dan ruang dan surat menyurat.

Berdasarkan hasil penelitian yang telah dilakukan di MA NW Rumbuk tentang peran kepala sekolah dalam meningkatkan disiplin guru, temuan yang dikemukakan pada bagian ini berdasarkan paparan data yang diperoleh dilapangan dan dirumuskan berdasarkan interpretasi data. Penyajian temuan tersebut untuk menjawab pertanyaan penelitian sebagaimana yang telah ditetapkan pada Bab Pendahuluan. Temuantemuan tersebut sesuai yang ada yakni sebagi berikut: kepala sekolah sebagai, manajer, pendidik, administrator, motivator harus dapat diupayakan agar guru dan semua tenaga kependidikan yang ada dilingkungan sekolah selalu meningkatkan kemampuan dan tanggung jawab dengan memperhatikan kesejateraan, dan rasa kebersamaan untuk 
mencapai produktifitas kerja yang sesuia dengan yang telah ditetapkan. Seperti yang telah dijelaskan di atas mengengenai peran kepala sekolah dalam meningkatkan disiplin guru banyak usaha yang dilakukan kepala sekolah dalam meningkatkan kedisiplinan ini namun masi banyak kekurangan yang perlu diperhatikan sebagai seorang kepala sekolah, yakni dari berbgai situasi dan kondisi.

Dari keempat peran kepala sekolah MA NW Rumbuk tersebut, cukup meningkatkan kedisiplinan guru, walaupun ada sebagian kecil guru yang masih perlu di genjot lagi agar lebih disiplin. Setiap kepala sekolah tentunya tidak ada yang sempurna, pasti ada saja kekurangan dan kelebihan dari kepala sekolah, oleh karena itu peran kepala MA NW Rumbuk sangat berperan dalam meningkatkan kedisiplinan guru.

Kepemimpinan kepala sekolah di MA NW Rumbuk fungsinya yaitu sebagai, manajer, pendidik, motivator, administrator, sangat diperlukan dalam hal peran kepala sekolah dalam meningkatkan disiplin guru seperti yang dijelaskan di atas, hal tersebut bertujuan untuk meningkatkan kualitas pendidik dan kualitas peserta didik.

Namun peran atau kepemimpinan kepala sekolah belum sesuai dengan apa yang disharapkan. Kepemimipinan kepala sekolah merupakan kemampuan dari seorang pemimpin sekolah untuk mampu megerakan segala sumberdaya kepedidikanya dalam hal kedisiplinan dalam mejalankan tugas dan tanggung jawab secara optimal dan mampu mewujudkan tujuan pendiikan yang telah ditetapkan sebelunya. Yang paling penting adalah mengerakan menejemen sekolah dalam hal ini kepemimpinan atau (leadership). Sebab tujuan dari seorang pemimpin dalam meningkatkan disiplin memberikan arahan dan menciptakaniklim kerja yang mendukung terlakanananya manejen kepala sekolah secara keseluruhan.

\section{SIMPULAN}

Peran kepala sekolah MA NW Rumbuk dalam peningkatan kinerja Guru ada beberapa peran yang dilakukan diantaranya adalah:

1. Kepala sekolah sebagai manajer, memiliki peran yang kuat dalam mengkoordinasikan, menggerakkan dan menyelerasikan semua sumber daya pendidikan yang tersedia di sekolah. Kepala sekolah tetap mengawasi, melakukan control serta evaluasi setiap program dan kinerja guru.

2. Kepala sekolah sebagai pendidik, hal yang di didik kepala sekolah adalah kecerdasan pikiran sehingga pendidikan dapat diartikan proses pengubahan sikap dan tata laku seseorang atau kelompok orang dalam usaha mendewasakan manusia melalui pengajaran dan pelatihan. 
3. Kepala Sekolah sebagai administrator yaitu, kepala sekolah harus mampu menguasai tugas-tugasnya dan melaksanakan tugasnya dengan baik. Untuk itu kepala sekolah harus kreatif mampu memiliki ide-ide dan inisiatif yang menunjang perkembangan sekolah.

4. Kepala Sekolah Sebagai Motivator, motivator kepala sekolah merupakan suatu bagian yang sangat penting di sekolah, guru dan pegawai akan bekerja dengan sungguh - sungguh apabila memiliki motivasi yang tinggi. Apabila guru dan pegawai memiliki motivasi positif maka guru dan pegawai akan lebih memperlihatkan minat, mempunyai perhatian dan ingin ikut serta dalam suatu tugas dan pekerjaan

\section{DAFTAR PUSTAKA}

Burhan, Bungin, 2008. Metode Penelitian Kuantitatif. Kencana: Jakarta.

Effendy, O. U. 2005. Kepemimpinan dan Komunikasi. Bandung: Alumni

Etzioni, Amitai. 1982. Organisasi-organisasi Modern. Alih bahasa oleh Suryatim. Jakarta: diterbitkan atas kerja sama Universitas Indonesia dan Pustaka Bradjaguna.

Geriya, I Wayan. 2009. Kota Kreatif Berbasis Budaya Unggulan Pendekatan Konseptual. In Yasa, IGW Marjana (Ed). 2009. Denpasar Kota Kreatif Berbasis Budaya Ungulan. Denpasar: Bappeda Kota Denpasar.

Ma'rat. 2001. Sikap Manusia: Perubahan Serta Pengukurannya. Bandung: Ghalia Indonesia

Soekanto. S. 2002. Sosiologi. Jakarta: PT Raja Grafindo Persada

Wahjosumidjo. 2007. Kepemimpinan Kepala Sekolah. Jakarta: PT Raja Grafindo Persada. 